\title{
BIOLOGICAL ASPECTS AND PREDATION EFFICACY OF CORANUS AEGYPTIUS (F.) ON THE SECOND LARVAL INSTAR, SPODOPTERA LITTORALIS (BOISD.) UNDER THE LABORATORY CONDITIONS \\ El-Maghraby, M.M.A.*; Sh. A.M. Ali** and A.A.A. Saleh ** \\ * Plant Protection Dept., Fac. of Agric., Zagazig Univ., Egypt \\ **Plant Protection Res. Institute, ARC, Dokki, Giza, Egypt
}

\begin{abstract}
Laboratory experiments were carried out in plant protection research Institute, Sharkia Branch, to study, some biological aspects and predation efficacy of the predator, Coranus aegyptius (Fabricius) (Hemiptera: Reduviidae) which recorded last decades on several economic and wild plants in El-Khattara district, Sharkia Governorate, Egypt, during 2012 and 2013 years. Some biological aspects and predation of this predator was investigated using the second larval instar of the cotton leaf worm, Spodoptera littoralis (Boisd.) as restricted prey under the conditions of 30 $\pm 1^{\circ} \mathrm{C}$ and $65+5 \%$ R.H. Egg stage incubation period lasted 7.30 days for the male and female. The five nymphal instars were recorded. The total developmental period and adult longevity were shorter in case of male 36.86 and 21.2 days, respectively than in case female, it were 38.85 and 61.2 days, respectively. Pre, oviposition and post ovipostion periods were $4.4,50.7$ and 6.6 days, respectively. The feeding capacity of nymphal stage and adult were 219.15 and 744.3 S. littoralis, larvae respectively for female. Its were 200.0 and 236.7 larvae respectively in case of male. The total number of deposited eggs were $220.5 \pm 11.69$ eggs, throughout an ovipositional period of $50.7+3.93$ days. These results showed that $C$. aegyptius can play an important role in biological control of cotton leaf worm $S$. littoralis in the field in economic crops in Egypt.
\end{abstract}

\section{INTRODUCTION}

Reduviids are abundant, occur world wide and are highly successful polyphagous predators play a vital role in the biocontrol of insect pests (ElShazly and El-Sebaey 1997, El-Sebaey 2001, El-Sebaey \& El-Bishry 2001 and Kumar et al., 2011). They exploit the most adverse microhabitals of agroecosystem. However, they exhibit a certain amount of hosts as well as stage preferences. Hence, they should be conserved and augmented to be effectively utilized in the Integrated Pest Management (IPM) programs (Ambrose, 2003, Ambrose et al., 2007 \& 2009 and Kumar et al., 2011). Coranus aegyptius (F.) is distributed in Palma de Mallorea, Canary Islands, Palearctic Region to Equatorial Africa (Capriles, 1990). In Egypt, C. aegyptius was found allover the country on several wild and cultivated host plants including Ranthium spinosum L. (compositae), Chenopodium murale L. (Malvaceae) and Ammimajus L. (Umbellifera), in addition to citrus trees and tomatoes (El-Sebaey 1994). Certain biological aspects of C. aegyptius was studied in the laboratory according to literature for the first time by using Anagasta kuehniella Zell. Larvae as prey (El-Sebaey 1998). Coranus africana (El-Sebaey) has recently been described from Egypt, associating with several 
insect pests on different economic plants including cotton, tomato, clover and several wild desert plants in Egypt (Ali 1996, El-Sebaey and El-Bishry, 2001 and Ali, 2008). It was collected from different localities in Egypt including kom Oshim, El-Khattara, Sharkia, Behera, Wadi El-Natroun district, Giza and Sinai Governorate. Some biological aspects of this species were investigated using third larval instar of the cotton pests, Spodoptera littoralis and Agrotis ipsilon (Rott.) (El-Sebaey, 2001) and other pests (Awadalla et al., 1990 ; ElShazly \& El-Sebaey , 1997 and Kumar et al., 2011) Reduviidae can suppression of whitefly, aphids and cotton leaf worm (El-Sebaey and ElWahab 2003, Faragalla 2004 and Amro and Abdel-Galil 2012). The present work was urged to study some biological aspects, feeding capacity and predation efficacy of $C$. aegyptius to facilitate its possible use in integrated pest management programs in economic crops in Egypt.

\section{MATERIALS AND METHODS}

\section{Laboratory cultures}

A culture of the cotton leaf-worm, Spodoptera littoralis (Boisd) was maintained according to the methods adopted by El-Maghraby (1984).

A laboratory culture of Coranus aegyptius (F.) was initiated from adults collected from the fields at El-Khattara district, Sharkia Governorate, Egypt. Biological experiments.

Experiments were conducted at $30 \pm 1^{\circ} \mathrm{C}$ and $65 \pm 5 \% \mathrm{R}$.H. Adults and immature stages of $C$. aegyptius were collected from fruit, ornamental trees and cotton field infested with aphids, whitefly and cotton leaf worm in newly reclaimed sandy area of El-Khattara district, Sharkia Governorate, Egypt by means of an insect sweep net or picking by hand, brought to the laboratory in Plant Protection Research Institute, Sharkia branch, where they were reared on cotton leaf worm and cotton aphid.

Deposited eggs of the predator were collected daily, kept separately in plastic vials $7 \times 2 \mathrm{~cm}$., until hatching and the newly hatched nymphs were supplied with enough numbers of the second larval instar of $S$. littoralis. Number of offered preys was increased as the predator nymphs grew older. Number of consumed larvae and predator nymphs molted were recorded daily until each nymph was developed to the adult stage. Other fifty newly hatched nymphs were supplied with enough numbers of Aphis gossypii individuals.

The number of offered preys was increased as the predator nymphs grew older. Number of consumed individuals and nymphs molted were recorded daily. Fifty replicates were individuals used. Newly emerged adults were sexed and each pair (one male and female) was placed in plastic vials $7 \times 2 \mathrm{~cm}$ for mating and egg deposition. Eggs laid by mated females were collected daily, counted and recorded. Pre, ovi, post oviposition periods, total number of eggs / female and longevity (female and male) were recorded. Ten couples were used as replicate. 


\section{Data analysis}

The means were separated using Dancan's Multiple Range Test (CoHort Software, 2004).

\section{RESULTS AND DISCUSSION}

\section{Egg stage}

The obtained data in Table (1) showed that the incubation period of egg stage lasted $7.30 \pm 0.07$ days with an range of (7-8) days, for eggs laid by females fed on the second instar larvae of $S$. littoralis. Meanwhile, ElSebaey (1998) found that incubation period of $C$. aegyptius egg when the females fed on Anagasta kuehniella Zell larvae as prey was $11.0+1.0$ days (7-12) at $30 \pm 1^{\circ} \mathrm{C}$ and $70.0 \pm 5 \%$ R.H. and El-Sebaey (2001) mentioned that incubation periods of Coranus africana were 10.5 and 12.1 days for eggs laid by females fed on the third instar larvae of $S$. littoralis and A.ypsilon respectively.Also, El-Sebaey and El-Bishry (2001) reported that the incubation period of $C$. africana eggs when the females fed on the two tested preys Anagasta Küehniella Zell. or Corcyra cephalonica larvae were 9.5 and 8.5 days respectively.

\section{Nymphal stage}

Coranus aegyptius nymphal stage passes through five instars (Table 1), under the laboratory conditions of $30 \pm 1^{\circ} \mathrm{C}$ and $65 \pm 5 \%$ R.H., and with feeding on the second instar larvae, $S$. littoralis. The first nymphal instar lasted $5.73 \pm 0.13$ and $5.89 \pm 0.14$ days for male and female, respectively. The second instar recorded $4.09 \pm 0.15$ and $4.33 \pm 0.14$ days for male and female, respectively. The third instar occupied $3.91 \pm 0.09$ days for male and $3.96 \pm 0.12$ days for female showing insignificant variation. The fourth instar lasted $6.09 \pm 0.28$ and $7.03 \pm 0.19$ days for male and female, respectively, being highly significantly $(F=9.28)$ varied. While the fifth instar nymphal period recorded $9.77 \pm 0.27$ days for male and $10.33+0.20$ days for female. No mortality could be detected during the first, $2^{\text {nd }}, 3^{\text {rd }}, 5^{\text {th }}$ instars except the fourth one as it recorded $2 \%$ mortality El-Sebaey (1998) mentioned the first to fifth nymphal instars lasted $6.5,6.1,5.7,5.9$ and 9.4 days, respectively for male. The respective values for female were $6.3,4.6,5.1$ and 6.8 days by using $A$. kuehniella larvae as prey, under conditions of $30 \pm 1^{\circ} \mathrm{C}$ and $70 \pm$ $5 \%$ R.H. .

Total nymphal period: Feeding on the second larval instar of $S$. littoralis the total nymphal period lasted 36.86 days in male, opposed to 38.85 days for female; being highly significant $(F=35.84)$ varied. These findings are in full agreement with those of El-Sebaey (1998) found that total nymphal period averaged 24.6 and 27.6 days for male and female respectively, by feeding A. kuehniella larvae, El-Sebaey (2001) in Egypt who used S. littoralis larvae as a prey for Coranus africana, as the five nymphal instars lasted in respective $6,3.7,4.3,6.5$ and 23.88 days for female, opposed to 5.3, 3.6, $5.2,6.3$ and 21.6 days in male. On the other hand, the corresponding values associated with $A$. ypsilon larvae were $5.1,4.3,6.3,7.1$ and 24.78 days for female and 5.1, 4.8, 5.7, 6.8 and 24.33 days for males. The average total 
nymphal period increased from 43.0 and 42.0 days for females and males, respectively on $S$. littoralis to the respective periods of 44.42 and 46.4 days on $A$. ipsilon.

\section{Adult stage}

The female and male longevity of $C$. aegyptius when fed on $S$. littoralis lasted $61.2 \pm 3.75$ and $21.2 \pm 1.02$ days, respectively (Table 2). Meanwhile, El-Sebaey (1998) found the female lived an average of 154.9 days, while male exhibited a shorter adult longevity 96.5 days.

\section{Ovipositional periods}

The female of $C$. aegyptius deposits eggs singly in the close vicinity of the prey. First eggs were laid after a pre- ovipositional period of $4.4 \pm 0.16$ days. The total number of deposited eggs were $220.5 \pm 11.69$ eggs, throughout an ovipositional period of $50.7 \pm 3.93$ days. At the end of the life span, ovipositional ceased for a postovipositional period of $6.6 \pm 0.70$ days (Table 2). El-Sebaey (1998) found that first egg of $C$. aegyptius was laid after an average preoviposition period of 7.2 days, the female deposited an average of 241.4 eggs throughout an oviposition period of 145 days, postoviposition period was 3.43 days, by using A. kuehniella larvae, ElSebaey (2001) found that mean of pre, ovi, postoviposition and total longevity periods of $C$. africana fed on the third larval instar of the cotton leaf worm, $S$. littorals were 10.1, 79.09, 10.0 and 100 days, while male life span was 98.4 days. Generally, biological activity of Coranus adults depended on prey type used. The oviposition period, egg laying activity and survivorship rate were better on $S$. littoralis than on $A$. ypsilon. Variation of these parameters is well documented and emphasized by previous authors (e. g. El-Sebaey 1989 \& 2001). However, the total number of eggs laid per female fed on $S$. littoralis larvae was 220 eggs higher than those fed on $A$. ypsilon (172.0 eggs/ female).

\section{Food consumption}

Coranus aegyptius developed and reproduced successfully when reared on the second larval instar of $S$. littoralis.

The average number of consumed larvae, increased generally with the development of various nymphal stage. The mean number of larvae consumed during the five nymphal instars were $23.0 \pm 0.74,24.27 \pm 0.86$, $24.36 \pm 0.59,43.45 \pm 2.23$ and $84.91 \pm 2.06$ larvae respectively, in case of male. It were $23.11 \pm 0.68,27.15 \pm 0.82,24.37 \pm 0.81,50.74 \pm 1.34$ and $93.78 \pm 1.90$ larvae respectively, per female. The total nymphal stage consumed $219.15 \pm 1.61$ larvae / female, while it were $200.0 \pm 2.63$ larvae / male. This indicated a significant differences $(F=5.919)$. Adult consumed $744.3 \pm 38.65$ and $236.7 \pm 11.05$ larvae during the longevity of female and male, respectively . With a highly significant differences $(F=159.42)$ (Table 3 ). The daily numbers of $S$. littoralis larvae consumed through the five nymphal stadia were in respective $5.33,7.6,9.5,10.5$ and 12 larvae, $C$. aegyptius female and male consumed daily 15.6 and 14.6 larvae of $S$. littoralis (El-Sebaey 2001). 
Table (1):Duration period ( in days) of immature stages of Coranus aegyptius when fed on the second instar larvae of Spodoptera littoralis at $30 \pm 1{ }^{\circ} \mathrm{C}$ and $65 \pm 5 \%$ R.H.

\begin{tabular}{|c|c|c|c|c|c|c|c|}
\hline \multirow{2}{*}{$\begin{array}{r}\text { Biological } \\
\text { aspects }\end{array}$} & \multicolumn{6}{|c|}{ Duration period of immature stages (in days) } & \multirow{3}{*}{$\begin{array}{c}\text { Total } \\
\text { developmental } \\
\text { period }\end{array}$} \\
\hline & Incubation & \multicolumn{5}{|c|}{ Nymphal stage } & \\
\hline Sex & $\begin{array}{l}\text { period of } \\
\text { egg stage }\end{array}$ & $1^{\text {st }}$ & $2^{\text {nd }}$ & $3^{\text {rd }}$ & $4^{\text {th }}$ & $5^{\text {th }}$ & \\
\hline Female & $\begin{array}{c}7.30 \pm 0.07^{a} \\
(7-8)\end{array}$ & $\begin{array}{c}5.89 \pm 0.14 \\
(5-7)\end{array}$ & $\begin{array}{c}4.33 \pm 0.14 \\
(3-6)\end{array}$ & $\begin{array}{c}3.96 \pm 0.12^{2} \\
(3-5)\end{array}$ & $\begin{array}{c}7.03 \pm 0.19 \\
(5-9)\end{array}$ & $\begin{array}{c}10.33 \pm 0.20^{2} \\
(8-12)\end{array}$ & $\begin{array}{c}38.85 \pm 0.16^{a} \\
(38-41)\end{array}$ \\
\hline Male & $\begin{array}{c}7.30 \pm 0.07^{\mathrm{a}} \\
(7-8)\end{array}$ & $\begin{array}{c}5.73 \pm 0.13 \\
(5-7)\end{array}$ & $\begin{array}{c}4.09 \pm 0.15 \\
(3-5)\end{array}$ & $\begin{array}{c}3.91 \pm 0.09^{\circ} \\
(3-5)\end{array}$ & $\begin{array}{c}6.09 \pm 0.28 \\
(4-8)\end{array}$ & $\begin{array}{c}9.77 \pm 0.24^{a} \\
(8-12)\end{array}$ & $\begin{array}{c}36.86 \pm 0.27^{b} \\
(34-39)\end{array}$ \\
\hline F. value & 0.403 & 0.047 & 2.053 & 0.074 & $9.28^{\star *}$ & 1.919 & $35.84^{\star * *}$ \\
\hline L.S.D. & & & & & & & \\
\hline 0.05 level & 288 & 0.422 & 0.447 & 0.335 & 0.692 & 0.662 & 0.735 \\
\hline 0.01 level & 0.385 & 0.564 & 0.598 & 0.448 & 0.925 & 0.885 & 0.983 \\
\hline
\end{tabular}

Table (2): Longevity of adult Coranus aegyptius and number of deposited eggs/ female when fed on the second instar larvae of Spodoptera littoralis at $30 \pm 1{ }^{\circ} \mathrm{C}$ and $65 \pm 5 \%$ R.H.

\begin{tabular}{|l|c|c|c|}
\hline Adult stage & Minimum & Maximum & Average \\
\hline Longevity / days & & 5 & $4.4 \pm 0.16$ \\
\hline Preoviposition period & 4 & 74 & $50.7 \pm 3.93$ \\
\hline Oviposition Period & 35 & 11 & $6.6 \pm 0.70$ \\
\hline $\begin{array}{l}\text { Post oviposition } \\
\text { period }\end{array}$ & 5 & 83 & $61.2 \pm 3.75$ \\
\hline $\begin{array}{l}\text { A- Female } \\
\text { B- Male }\end{array}$ & 45 & 26 & $21.2 \pm 1.02$ \\
\hline $\begin{array}{l}\text { Total No. of } \\
\text { eggs/female }\end{array}$ & 17 & 288 & $220.5 \pm 11.69$ \\
\hline
\end{tabular}

Table (3): Feeding capacity of nymphal stage and adults of Coranus aegyptius fed on the second instar larvae of Spodoptera littoralis at $30 \pm 1{ }^{\circ} \mathrm{C}$ and $65 \pm 5 \%$ R.H.

\begin{tabular}{|c|c|c|c|c|c|c|c|}
\hline \multirow{3}{*}{$\begin{array}{r}\text { Biological } \\
\text { aspects }\end{array}$} & \multicolumn{5}{|c|}{ Average and range of consumption } & \multirow{3}{*}{$\begin{array}{c}\text { Total } \\
\text { consumption/ } \\
\text { nymph }\end{array}$} & \multirow{3}{*}{\begin{tabular}{|c|} 
Total \\
consumption \\
/ adult
\end{tabular}} \\
\hline & \multicolumn{5}{|c|}{ Nymphl stage } & & \\
\hline & $1^{\text {st }}$ & $2^{\text {nd }}$ & $3^{\text {rd }}$ & $4^{\text {th }}$ & $5^{\text {th }}$ & & \\
\hline \begin{tabular}{|l|} 
A- \\
Female \\
\end{tabular} & $\begin{array}{c}23.11+0.68^{\mathrm{a}} \\
(19-32)\end{array}$ & $\begin{array}{c}27.15 \pm 0.82^{a} \\
(19-36)\end{array}$ & $\begin{array}{c}24.37 \pm 0.81^{a} \\
(17-32)\end{array}$ & $\begin{array}{c}50.74 \pm 1.34^{a} \\
(35-64)\end{array}$ & $\begin{array}{c}93.78+1.90^{\mathrm{a}} \\
(72-113)\end{array}$ & $\begin{array}{c}219.15 \pm 1.61^{a} \\
(204-236)\end{array}$ & $\begin{array}{c}744.3 \pm 38.65^{a} \\
(550-918)\end{array}$ \\
\hline B- Male & $\begin{array}{c}23.0 \pm 0.74^{\mathrm{a}} \\
(18-30)\end{array}$ & $\begin{array}{c}24.27 \pm 0.86^{\circ} \\
(16-34)\end{array}$ & $\begin{array}{c}24.36 \pm 0.59^{\mathrm{a}} \\
(18-31)\end{array}$ & $\begin{array}{c}43.45 \pm 2.23^{\circ} \\
(23-58)\end{array}$ & $\begin{array}{c}84.91 \pm 2.06^{\mathrm{a}} \\
(70-104)\end{array}$ & $\begin{array}{c}200.0 \pm 2.63^{b} \\
(175-219)\end{array}$ & $\begin{array}{c}236.7 \pm 11.05^{b} \\
(195-280)\end{array}$ \\
\hline F. value & 0.004 & $5.876^{\star}$ & 0.219 & $9.693^{\star *}$ & 0.557 & $5.919^{*}$ & $159.417^{* \star *}$ \\
\hline \multicolumn{8}{|l|}{ L.S.D. at: } \\
\hline 0.05 level & 2.681 & 2.535 & 2.545 & 5.303 & 10.069 & & 62 \\
\hline 0.01 level & 3.585 & 3.389 & 3.403 & 7.090 & 13.463 & 15.828 & 115.720 \\
\hline
\end{tabular}




\section{REFERENCES}

Ali, Sh. A.M. (1996). Natural enemies in EL-Khattara district. M. Sc. Thesis, Fac. of Agric., Zagazig Univ., pp. 222.

Ali, Sh. A.M. (2008). Relationship between aphids and aphidophagous insects in El-Khattara district. Ph. D. Thesis, Fac. of Agric., Zagazig Univ., pp. 191.

Ambrose, D.P. (2003). Biocontrol potential of assassin bugs (Hemiptera: Reduviidae). J. Exper. Zool., India, 6 (1):1-44.

Ambrose, D.P. ; X.J.S. Rajan; K. Nagarajan, V.J. Singh and S.S. Krishnan (2009). Biology, behaviour and functional response of Sphedanolestes variabilis Distant (Insecta: Hemiptera: Reduviidae: Harpactorinae) apotential predator of lepidopteran. Pests. Entomologia Croatica, 13(2):33-44.

Ambrose, D.P.; S.Gunaseelan ; S. S. Krishnan ; V. Jebasingh and B. Ravichandran (2007). Red scription, biology and behaviour of a harpactorine assassin bug Endochus migratorius distant. Hexapoda 14 (2): 89-94.

Amro, M.A. and F.A. Abdel-Galil (2012). Can entomophagous heteroptera take a role in suppressing herbivorous insect pests? IOBC/WPRS Bulletin, 75:9-12.

Awadalla, K. T.; A.I. Afifi and I.I. A. El-Sebaey (1990). The biology of the reduviid, Allaeocranum bianmulipes (Mont. \& Sign.) Apredator of stored product insect pests. Bull. Soc. Ent. Egypt., 69: 169-181.

Capriles, J.M. (1990): Systematic catalogue of the reduviidae of the world (Insecta: Heteroptera). Caribbean J. Sci. (A special Edition), pp. 694.

CoHort Software (2004). CoStat. www.CoHort com.Monterey, Calfiornia, U.S.A.

El-Maghraby, M.M.A. (1984): Der Einflu $\beta$ van Bacillus thuringiensis Berliner auf Zwei Wirt-Parasit-Systeme Spodoptera littoralis (Boisd.) -Microplitis rufiventris Kok.; Pieris brassicae L.-Apanteles glomeratus L. Dissertation Zur Erlangung des Doktorgrades der Landwirtschaftilchen Fakültat der Georg-August Univ. Gôttingen.

El-Sebaey, I.I.A. (1989). Studies on the natural enemies of stored feed meal pests. M. Sc. Thesis, Fac. of Agric., Cairo Univ., 351-pp.

El-Sebaey, I.I.A. (1994): Taxonomical and biological studies of family Reduviidae in Egypt. Ph. D. Thesis, Fac. of Agric., Cairo Univ., 351 pp.

El-Sebaey, I.I.A. (1998): Biological and morphological studies on Coranus aeguyptius F. (Hemiptera: Reduviidae). Egypt. J. Agric. Res. , 76 (3): 933-945.

El-Sebaey, I.I. A. and M.H. El-Bishry (2001). Biological aspects and predation of Coranus africana El-Sebaey (Heteroptera: Reduviidae: Harpactorinae) on the laboratory preys Anagsta kuehniella and Corcyra cephalonica. Egyptian . J. Biol. Pest Cont. 11 (1/2): 57-62. 
El-Sebaey, I.I. A. and H. A.A. El-Wahab (2003). Suppression of Bemisia tabaci (Genn.), Aphis gossypii Glover and Spodoptera littoralis (Bosid.) by Coranus africana El-Sebaey (Hemiptera, Heteroptera, Reduviidae) in a tomato field. Bull. Fac. Agric. Cairo Univ. 54 (1): 141-150.

El-Sebaey, I.I. A.(2001). Biology and predation rates of certain adult Reduviids (Hemiptera: Heteroptera). Egyptian J. Biol. Pest. Cont. 11 (1): 15-23.

El-Shazly, M.M. and I.I. El-Sebaey (1997). Development and predation rates of Coranus aegyptius (F.) and Vachiria natolica Stal (Hemiptera: Reduviidae: Harpactorinae). Ibid. 7 (1): 47-51.

Faragalla, A.A. (2004). The role of some major aphidophagous predators on major aphid species in alfalfa agroecosystem, Western Saudi Arabia. Assiut J. Agric. Scie., 35 (3):261-287.

Kumar, A.G.; K. Rajan; S.J. Rajan and D. P. Ambrose (2011). Predatory behaviour of an assassing bug, Coranus spiniscutis (Reuter) on rice meal moth Corcyra cephalonica (Stainton) and leaf army worm, Spodoptera litura (Fabricius). Entomol. Res. Unit, St. Xavier's College. Palayamkottai, India, pp. 404-408.

Coranus الخصــائص البيولوجيــة والافتراســية للمفتـرس الروديفييــــ

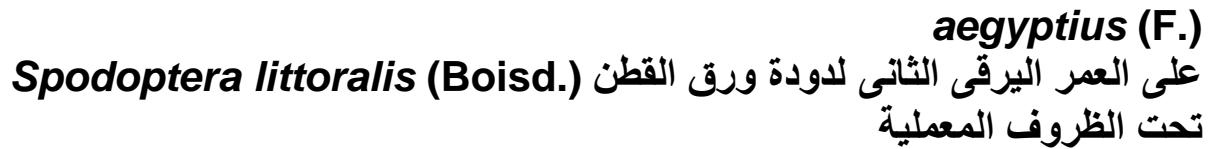

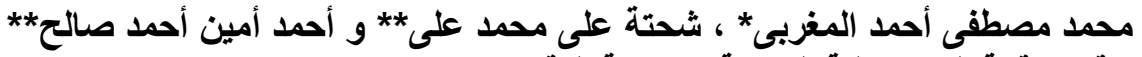

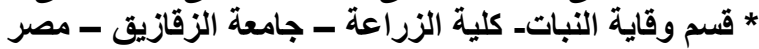
* معهد بحوث وقاية النباتات ـ مركز البحوث الزراعية ـ الاقيى ـ الجيزة ـ مصر

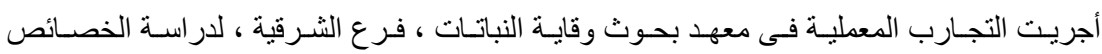

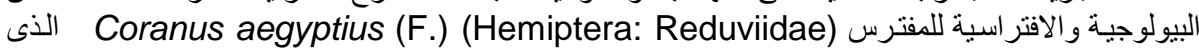

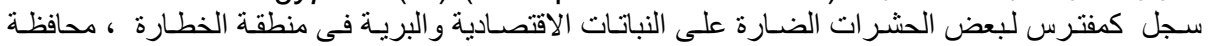

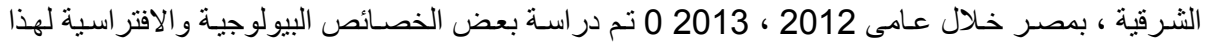
الدفترس باستخدام يرقات العمر الثانى لدودة ورق القطن

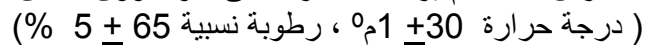

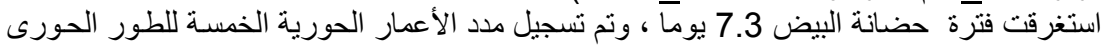

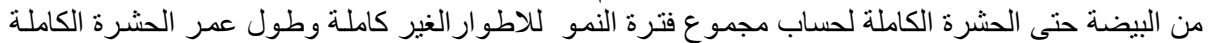

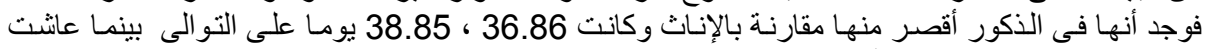

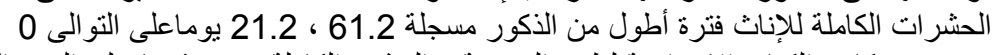

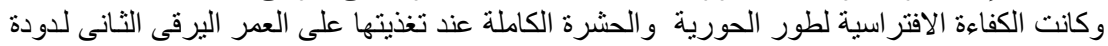

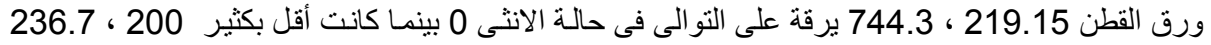

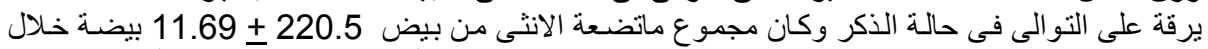

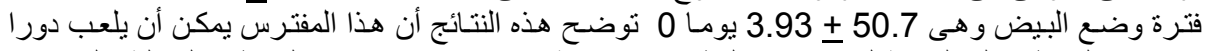

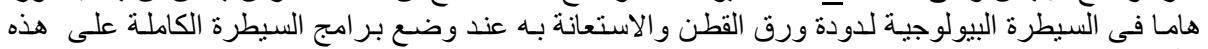

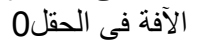

